\title{
The Mediating Role of Psychological Empowerment in the Relationship between the Empowering Leadership Behavior and Work Engagement: A Study Applied on the Cement Sector in Upper Egypt
}

\author{
Adel R. M. Rayan ${ }^{1}$, Ahmed S. M. Sebaie ${ }^{2} \&$ Nagwa A. Ahmed ${ }^{2}$ \\ 1 Faculty of International Business and Humanities, Egypt-Japan University of Science and Technology \\ (E-JUST), Egypt \\ ${ }^{2}$ Faculty of Commerce, Assiut University, Egypt \\ Correspondence: Adel R. M. Rayan, Faculty of International Business and Humanities, Egypt-Japan University \\ of Science and Technology (E-JUST), Egypt. E-mail: adel.rayan@ejust.edu.eg
}

Received: September 20, 2018

doi:10.5539/ijbm.v13n12p18
Accepted: October 12, $2018 \quad$ Online Published: November 12, 2018

URL: https://doi.org/10.5539/ijbm.v13n12p18

\begin{abstract}
This study aims to test the relationship between perceived empowering leadership behavior and the work engagement. Also, the mediating role of psychological empowerment in this relation has been examined. The study applied on a sample of 360 employees at the Egyptian cement industry in Upper Egypt. Data was collected using work engagement questionnaire based on the Schaufeli, Salanova, González-Romá, and Bakker (2002) scale. The current study used the scale of the Zhang \& Bartol study (2010), prepared by Ahearne et al., (2005) to measure the empowering leadership behaviors. Psychological empowerment has been measured using Spreitzer (1995) and Zhung and Bartol (2010).

The study was conducted using the Statistical Package for Social Sciences (SPSS) program in data processing for AMOS to test the quality of compatibility between the collected data and the theoretical data, and the structural model to test the study hypotheses.

The results did not support the direct relationship between leadership empowered behavior and work engagement. The empowering leadership behavior is positively affecting the psychological empowerment. Psychological empowerment was found to be positively affecting work engagement. However, the psychological empowerment was found to be mediating the relationship between the two variables. The study reached some conclusions related to this relationship and how to have it enhanced in the Cement industry in Upper Egypt.
\end{abstract}

Keywords: psychological empowerment, empowering leadership behavior, work engagement

\section{Introduction}

Recent economic and political situation of many Egyptian business organizations have increased the interest in understanding and developing effective leadership. Fighting corruption in Egypt does not need issuing more laws and regulations. More regulations bread corruption. The problem in Egypt, according to World Justice Project ( WJP) data, was not so much that the country lacked the regulations needed to crack down on corruption but that it failed to enforce them (World Bank, 2014). Creating a healthy climate in Egyptian organizations through transparency, trust and empowerment will help reducing corruption in these organizations. Having empowered leaders who can enforce law in organizations and empowered employees will help in creating healthy work place where employee well-being and high performance are maintained. Leaders play an important role in employees' well-being and performance. The successful leader shares power and control, engages employees (Winston, and Patterson, 2006) and is concerned for empowerment (Shelton, 1997).

New directions in leadership research focus more on the positive leadership role in organizations. In this sense, empowering leaders is very important in managing and enabling subordinates. Empowering leadership behaviors are positively affecting the work outcomes in organizations. Ahearne, Mathieu and Rapp (2005) proved that empowering leadership behaviors can increase sales performance by enhancing salesperson's self-efficacy. Namasivayam, Guchait, and Lei (2014) study pointed out that empowering leadership leads to employees' psychological empowerment that in turn leads to customer satisfaction. Empowering leadership behavior is 
positively affecting employees' well-being and careers (Kim \& Beehr, 2018).

At the same time, work engagement as one of the positive work attitudes has an important impact on organizations' outcomes (Kumar \& Pansari, 2014; Harter, Schmidt, Agrawal, \& Plowman, 2013). To consolidate the concept of work engagement, there are some psychological conditions should exist such as: meaningfulness, safety and availability (Khan, 1990). This means that employees who experience psychological empowerment feel that their contribution are meaningful and they possess the ability to shape their work environment (Gregory, Albritton, \& Osmonbekov, 2010; Klerk \& Stander, 2014).

It is therefore important to examine the direct influence of the empowering leadership behavior on work engagement in the Egyptian context in the Cement sector and to define the role of psychosocial empowerment as a mediating variable through which a leader can influence the subordinates. The Cement sector in Egypt is one of the important industries in Egypt. It consists of 25 companies employing 16553 employees, producing 58 Million tons of cement and yielding about 450 million Egyptian Pounds every year (Industrial Development Authority, 2018). This study is applied on four companies in Upper Egypt in order to explore the above mentioned relationships between the study variables.

\section{Prior Literature and Study Hypothesis}

\subsection{Perceived Empowering Leadership Behavior and Work Engagement}

Conger and Kanungo (1988) and Hui (1994) identified five set behaviors of the empowered leader. The first one is enhancing the meaningfulness of work, which describes the way the leader uses to expand work responsibilities to make the work more meaningful to employees. The second set of behaviors includes fostering participation in decision making, which gets employees involved in making work-related decisions. The third and fourth sets of behaviors include providing autonomy from bureaucratic constrains and supporting goal achievement. The fifth set of behaviors is expressing confidence in high performance which help reflecting the values and beliefs of the leader on employees' capabilities. These sets of behaviors are formulated later in four dimensions of empowered leader behaviors scale of 12 items by Ahearne et al. (2005).

The empowered leader's behavior is different from that of non-empowered (Burke, Stagl, Klein, Goodwin, Salas, \& Halpin, 2006; Tuckey, Bakker, \& Dollard, 2012). The empowered leader's behavior helps facilitate the self-managed employees where opportunities of job learning and independence at work exist. This in turn will be reflected positively on job satisfaction, organizational commitment (Peachey, 2002; Dee \& Duemer, 2003; Avolio, Zhu, William, \& Bhatia, 2004; Carson \& King, 2005; Bordin, Bartram, \& Casimir, 2007).

When the leader behaves in a way which is perceived by the employees as an empowered leader, these behaviors are found to be positively correlated with work engagement (Rasheed, Khan, and Ramzan, (2013); Ram \& Prabhakar, 2011; Xu \&Thomas, 2010).

Schaufeli and Bakker (2004: 295) defined work engagement as "a positive, fulfilling, work-related state of mind that is characterized by vigor, dedication, and absorption".

Sze \& Angeline (2011) considered that work engagement is the most recent concept in relation to some other functional attitudes such as organizational commitment and job satisfaction, and this was reflected in the large number of researches that dealt with the job engagement as a structure characterized by several definitions and different dimensions. According to Schaufeli \& Bakker (2004), work engagement has three dimensions: vigor, dedication and absorption, where employees experience their work as stimulating and energetic to which they are devoting time and effort (vigor dimension): as a significant and meaningful pursuit (dedication dimension) and as engrossing and something on which employees are fully concentrated (absorption dimension).

The above noted literature revealed that there is a positive relationship between empowering leadership behavior and work engagement. Thus the first hypothesis of this study can be formulated as follows:

$H_{1}$ : "There is a positive relationship between the empowering leadership behavior and the work engagement"

\subsection{Perceived Leadership Empowerment Behavior and Psychological Empowerment}

Raub \& Robert (2012) stated that empowerment as a general concept is based on a set of practices that allows participation of all employees at all levels. Previous studies (e.g. Ahearne et al., 2005; Zhang \& Sims, 2005) have pointed out that the empowered leader with influence can support the psychological empowerment of his/her subordinates by giving those greater discretionary powers.

Hakimi, Van Knippenberg, and Giessner (2010) and Hui (1994) consider that the process of psychosocial empowerment is empowering others, and requires that the subordinate be aware of the extent to which his /her leader is empowered to be able to empower him/her. Shelton (2002) study suggested that the psychological 
empowerment of employees should be a factor that plays a dual role in empowering the leader and empowering the subordinate.

Other studies (e.g. Raub \& Robert (2010); Randolph \& Kemery (2011); Boudrias, Gaudreau, Savoie, and Morin, (2009)) showed that there is a significant relationship between the empowering leadership behaviors and the psychological empowerment of his/her subordinates. The study of Peachey (2010) stated that the empowerment of subordinates is influenced by the behavior of the leader. That study assumed that non-official managers may be ineffective and unable to communicate or transfer psychosocial empowerment to their subordinates compared to those leaders with an influence and an official power. The study results showed that the empowering leadership behavior dimensions had a significant impact on the psychological empowerment dimensions.

The psychological empowerment dimensions are meaning of work, competence, self-determination and impact. Meaning of work was described as "the value of a work goal or propose, judge in relation to an individual's own ideals or standards "(Spreitzer, 1995; p. 1443). Competence, the second dimension was described as "an individual's belief in his or her capability to perform activities with skill" (Spreitzer, 1995, p. 1443). Third dimension, self-determination was described as "an individual's sense of having choice in imitating and regulating action" (Spreitzer, 1995, p. 1443). Impact dimension was defined as "the degree to which an individual can influence strategic, administrative or operating outcomes in the organization or larger environment" (Spreitzer, 1995, p. 1444).

The study of Zhang and Bartol (2010) examined the relationship between the behaviors of the empowered leader and the psychological empowerment at IT companies in China. The results showed a significant correlation between the empowering leadership behavior and the psychological empowerment of his subordinates. Their study identified a number of behavioral dimensions that reflect the behaviors of the empowered leader such as acting as role models, sharing information, guidance, granting independence, showing interest, and the promotion of work.

In their longitudinal study, Dierendonck \& Dijkstra (2012) presented a different view, which emphasizes the role of subordinates in the relationship between the empowering leadership behaviors and psychological empowerment.

The empowered leader supports workers' understanding of the meaning and importance of work by providing subordinates with information about the goals and mission of the organization. Also, the fact that the leader delegates power to his subordinates will give them more autonomy. Thus, the empowering leadership behavior is one of the main reasons for the psychosocial empowerment of subordinates (Amundsen \& Martinsen., 2015).

In the Egyptian context, Hayder (2001) studied the factors affecting the psychological empowerment of the employees. His study showed a statistically significant relationship between organizational support and psychological empowerment. El-Mobied and Awad (2003), tested the relationship between the psychological empowerment dimensions (Meaning of work, Competence, Self-determination and Impact) and the confidence in the leader. This relationship was found to be positive. Abdel Salam, Shawky, El-Nahass, \& Nawar (2013) examined the relationships between job satisfaction, motivation, leadership, communication, and psychological empowerment. Their study supported the positive relationship between leadership support and the above noted variables including psychological empowerment.

It is noted that the relationship between empowering leadership behavior and psychological empowerment of employees in the Egyptian context needs more examination by researchers. Based on that and on the previous studies results the second hypothesis is formulated as follows:

$H_{2}$ : "There is a positive relationship between the empowering leadership behaviors and the psychological empowerment"

\subsection{The Psychological Empowerment and Work Engagement}

The psychological climate within the work environment is one of the main reasons for the work engagement (Czarnowsky, 2008; O'Neill \& Arendt, 2008). Olivier and Rothmann (2007); and May, Gilson, and Harter (2004) studies dealt with the relationship between psychological climate and work engagement. The results of these studies showed a significant correlation between the psychological climate and work engagement.

Schaufeli and Bakker (2004) attributed the relationship between psychological empowerment and work engagement into the job demands and job resources models where each job has psychological, physical, social and organizational requirements. On the other side, each job has psychological, physical, social and organizational resources to meet these requirements. If these requirements are not met, the performance dysfunction and the turnover will increase. The psychological empowerment is one of the job resources that help 
meeting the job requirements (Ugwu, Onitsha, \& Rodríguez-Sánchez, 2014).

Olivier and Rothmann (2007); and May et al. (2004) studies dealt with the relationship between psychological climate and work engagement. The results of these studies showed a significant correlation between the psychological climate and work engagement.

Stander and Rothmann (2010) studied the relationship between psychological empowerment and work engagement in some industrial organizations in South Africa. They found a statistical relationship between the two variables. The relationship between psychological empowerment and work engagement has been confirmed by Taghipour and Dezfuli (2013) study.

In the Egyptian and Arab context, the research initiatives were limited to the relationship between the psychological empowerment and some positive attitudes at work such as s organizational commitment, job satisfaction and organizational loyalty (El-Mobied \& Awad, 2003; El-Sayed, 2003; and El-Masadi, 2003, Saif \& Saleh, 2013). The examination of the relationship between psychological empowerment and work engagement is not fully studied in the Egyptian context.

Based on the previous studies especially those conducted in the Egyptian context the third hypothesis is formulated as follows:

$\mathrm{H}_{3}$ : "There is a positive relationship between psychological empowerment work engagement".

\subsection{The mediation Role of Psychological Empowerment}

Greco et al. (2006) tested a model derived from the kantar model (1977), based on the idea that employees' attitudes are attributed more to individual and collective situations they face than that of their personal traits. Her study proved the relationship between psychological empowerment and work engagement. This relationship was found to be increased in the existence of some variables such as: functional variables, variables related to structural empowerment, working conditions, self-efficacy, and identification with the leader. Such variables contribute to the interpretation of the relationship between the behavior of the empowered leader and work engagement.

Ahrearne et al. (2005) and Albrecht and Andreetta (2011), attributed the mediating role of psychological empowerment to some reasons, including the existence of statistical significance relationship between the empowered leader behavior on one hand and psychological empowerment on the other hand, and also a statistical significant relationship between psychological empowerment in one hand and work engagement on the other hand.

The psychological empowerment was found to be mediating the relationship between leadership behaviors (transformational and transactional leadership) and the organizational identity of the subordinates (Zhu, Sosik, Riggio, and Yang. (2012)) and between the empowered leader's behavior and some work attitudes such as job satisfaction and creativity (Amundsen \& Martinsen, 2015), organizational commitment (Careless, 2004; Avolio, et al. 2004; Raub \& Robert, 2012). In the same context, Zhang and Bartol, (2010) concluded that empowering leadership is positively affecting psychological empowerment, which in turn influencing both intrinsic motivation and creative process engagement.

Menon (1999) suggested that employees differ in their willingness and responsiveness to the powers granted to them in perceiving the psychological empowerment would increase the preference of researchers to consider psychological empowerment as a mediating variable and this is what the study of Ghadi, Fernando, \& Caputi, (2012) indicated. That is employees differ in their perception of value and meaning of work.

Other studies (Albrecht \& Andreetta, 2011; Klerk \& Stander, 2014) dealt with the mediating role of psychosocial empowerment on the relationship between the empowering leadership behavior and the work engagement. However, the mediation effect of psychological empowerment on the relationship between the empowering leadership behavior and work attitudes including work engagement was varying from full mediation (Klerk \& Stander (2014)) to partial mediation (Raub \& Robert, 2012) based on the level of the relationship between the independent variable (empowering leadership behavior) and the dependent variable (work engagement) (Lorinkova \& Perry, 2017).

On the contrary, Lishchinsky and Tsemach (2014) study indicated that psychological empowerment did not mediate the relationship between authentic leadership and the withdrawal behaviors of lateness and intent to leave. In the Egyptian context, a study by Abdel Salam et al (2013 demonstrated a significant moderating effect of psychological empowerment and its dimensions on the relationship between motivation (intrinsic and extrinsic) and job satisfaction. It also showed a partially significant moderating effect of psychological 
empowerment and its dimensions on the relationship between leadership support and job satisfaction and between communication and job satisfaction.

It is concluded from the foregoing that some previous studies have confirmed that psychological empowerment as a mediator variable has played an additional role in the interpretation of work engagement. However, this additional role has not been confirmed by other studies. So, the fourth hypothesis will be formulated as follows:

$H_{4}$ : "The psychosocial empowerment is mediating the relationship between empowering leadership behavior and work engagement".

\section{Study model}

Based on the review of the previous literature and in order to achieve the objectives of the current study, a model has been developed for the current study. The model shown in Figure (1) shows the relations between the variables covered by the model in its three phases as follows:

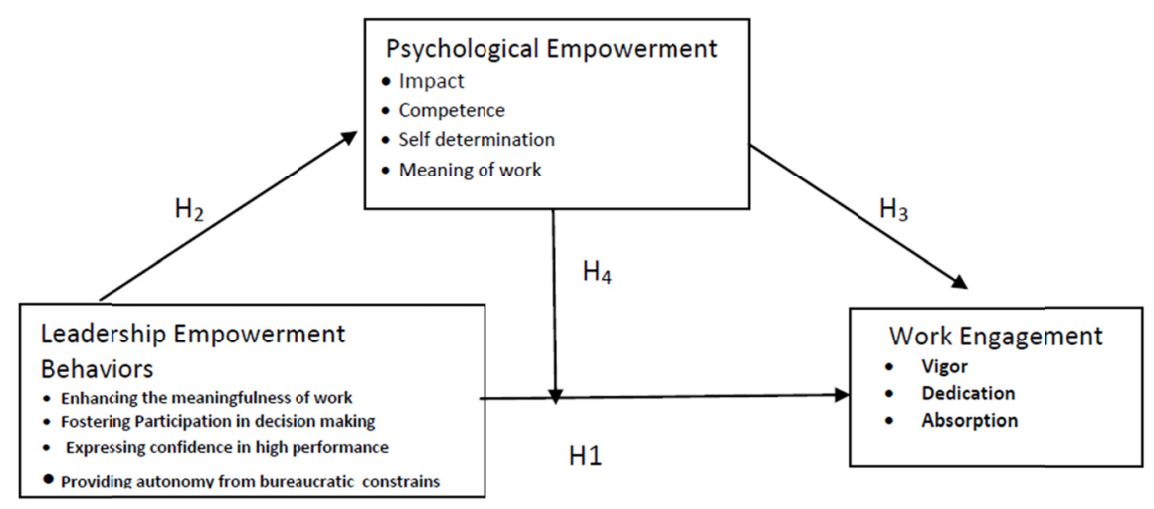

Figure 1. Hypothesized model of the study

\section{Study Methods and Measurement}

\subsection{Study Population and Sample}

The study population consists of four cement factories operating in three governorates in Upper Egypt. 80\% of these factories are owned by the private sector and $20 \%$ is owned by the public sector. These factories employ 5373 individuals. A sample of 450 employees has been selected and the returned questionnaires was 360 as shown in the following table:

Table 1. Sample distribution among factories

\begin{tabular}{|c|c|c|c|c|c|}
\hline Factory & Location & $\begin{array}{l}\text { Number } \\
\text { questionnaires } \\
\text { distributed } \\
\end{array}$ & of & $\begin{array}{l}\text { Number of } \\
\text { questionnaires } \\
\text { returned }\end{array}$ & Response rate (\%) \\
\hline Helwan Cement & Menya & 120 & & 98 & 81.2 \\
\hline Royal of Cement & Menya & 100 & & 79 & 79 \\
\hline Beni Sewif Cement & Beni Sewif & 110 & & 86 & 78.2 \\
\hline Al-Tameer Cement & Assiut & 120 & & 97 & 80.8 \\
\hline Total & & 450 & & 360 & 80 \\
\hline
\end{tabular}

Employees completed surveys assessing their supervisors' empowering leadership behaviors, and their own psychological empowerment and work engagement. The questionnaire was administered in Arabic, the English-language original having been translated into Arabic by the first author and back-translated into English by a professional translator, with the translation then checked for accuracy.

\section{Measurement}

A 5-points Likert scale response format ((5) Always-(1) Never) was used in the questionnaire of this study. 
The work engagement is measured through seventeen statement based on the Schaufeli, Salanova, González-Romá, and Bakker (2002) scale. This scale covers the three dimensions of job engagement: Vigor, Dedication, and Absorption. Examples of questionnaire items include:- (1) vigor: At my work, I feel bursting with energy, (2) for dedication:- Time flies when I am working and (3) for absorption:- When I am working, I forget everything else around me, and I get carried away when I am working.

The conformity factor analysis suggested single second-order analysis with an acceptable fit $\left(\mathrm{X}^{2} / \mathrm{df}=2.922\right.$, $\mathrm{CFI}=.980$, RMSEA $=.073$ ). This improvement has been made to have an acceptable fit. In turn 8 items of the scale have been deleted (items 4, 5, 6 and 7 from the first dimension: vigor; for the second dimension: dedication: items 1and 3, for the third dimension: absorption: items 1 and 5). Cronbach's Alpha for the whole scale is .922

Perceived empowering leadership behavior: The current study uses the scale of the Zhang \& Bartol study (2010), prepared by Ahearne et al., (2005). The measure, with 12 items, has four dimensions: enhancing the meaning of work, fostering participation in decision making, expressing confidence in high performance and providing autonomy from bureaucracy constraints. Examples of questionnaire items include:- (1) Enhancing the meaning of work: My manager helps me understand the importance of my work to the overall effectiveness of the company, (2) for Fostering participation in decision making:-My manager solicits my opinion on decisions that may affect me, (3) for Expressing confidence in high performance:- My manager expresses confidence in my ability to perform at a high level, and (4) for Providing autonomy from bureaucracy constraints:- My manager allows me to do my job my way.

The conformity factor analysis suggested single second-order analysis with an acceptable fit (X2/df $=2.258$, $\mathrm{CFI}=0.982, \mathrm{RMSEA}=.059)$. None of the scale items $(12)$ has been deleted. Cronbach's Alpha for the whole scale is .926 .

Psychological empowerment has been measured using Spreitzer [1995) and Zhung \& Bartol (2010). The measure consists of four dimensions as follows: meaning of work, competence, self-determination and impact. Examples of questionnaire items include:- I am confident about my ability to do my job, My job activities are personally meaningful to me, and The work I do is meaningful to me.

The conformity factor analysis suggested single second-order analysis with an acceptable fit $\left(\mathrm{X}^{2} / \mathrm{df}=2.286\right.$, $\mathrm{CFI}=0.979$, RMSEA=.056). None of the scale items (12) has been deleted. Cronbach's Alpha for the whole scale is .891.

\subsection{Statistical Methods Used in Data Analysis}

- The study used the Statistical Package for Social Sciences (SPSS) program in data processing for AMOS.

- The study used the Analysis of Moment Structures (AMOS). The present study used the structural equation model: the measurement model to test the quality of compatibility between the collected data and the theoretical data, and the structural model to test the study hypotheses.

- The Sobel (1982) standard was used to test the mediation effect of psychological empowerment.

\subsection{Statistical Analysis of Data}

Table 2 shows the correlation coefficients of study variables. The coefficients show that the leadership empowerment behaviors is correlated with the work engagement by .51 . The psychological empowerment is correlated with the work engagement by .61. All of these correlation coefficients are significant.

Table 2. Mean, Standard Deviation, Correlation's Coefficients and Cronbach's Alpha

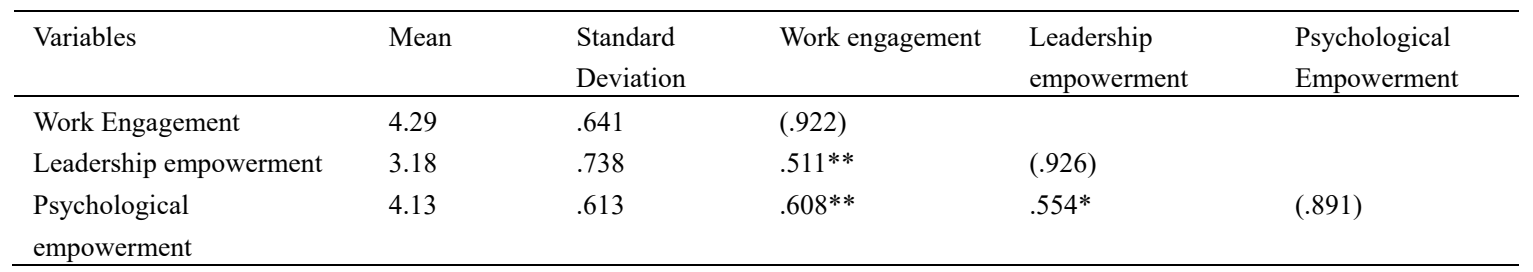

*correlation is significant at $0.05 . *$ correlation is significant at 0.01 .

Cronbach's Alpha is shown between brackets. 
The following figure shows the structural model of the study:

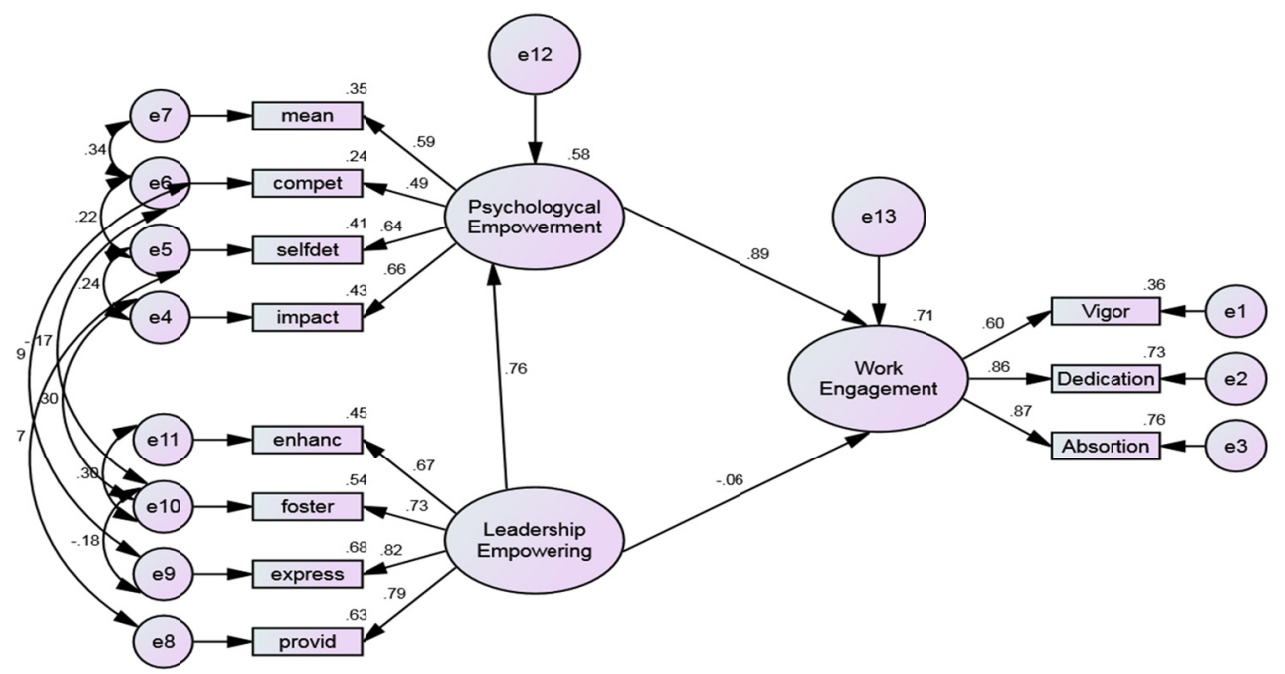

Figure 2. Structural model of the study

The first hypothesis states that: "There is a positive impact of the leadership empowerment behavior on work engagement dimensions. The results do not support this hypothesis, where $\beta=0.06$, and $\mathrm{SE}=0.297$, and $\mathrm{P}=$ 0.767 , which means that this relationship is not statistically significant, and thus the first hypothesis is not accepted.

The second hypothesis states: "There is a positive relationship between the leadership empowerment behavior and psychosocial empowerment of employees". The results showed that $\beta=.76, \mathrm{SE}=.088$ and $\mathrm{P}=0.001$. This means that the higher the leadership empowerment behavior, the higher the psychological empowerment and thus hypothesis (2) is accepted.

The third hypothesis states that "There is a positive relationship between psychological empowerment and work engagement". This hypothesis is supported by the results shown in table (3), where $\beta=0.89, \mathrm{~T}=5.058$, and $\mathrm{P}=$ 0.000 .

The fourth hypothesis states that "the psychological empowerment is mediating the relationship between the leadership empowerment behavior and the work engagement".

Table 3. Direct and indirect influence between study variables

\begin{tabular}{|c|c|c|c|c|}
\hline Paths & Indirect effect & Direct effect & Total effects & \\
\hline Empowering Leadership behavior $\longrightarrow$ Work engagement & 0.67 & -0.06 & 0.61 & \\
\hline Values of paths & $\begin{array}{l}\text { Standard } \\
\text { Coefficient }(\beta)\end{array}$ & $\begin{array}{l}\text { Standard } \\
\text { Error }\end{array}$ & $\begin{array}{l}\text { CR value } \\
(\mathrm{T})\end{array}$ & $\mathrm{P}$ \\
\hline Empowering Leadership behavior $\longrightarrow$ Work engagement & -0.06 & 0.150 & -0.427 & 0.67 \\
\hline Psychological Empowerment $\longrightarrow$ Work engagement & 0.89 & 0.187 & 5.058 & 0.000 \\
\hline Leadership empowerment behavior $\rightarrow$ Psychological empowerment & 0.76 & .088 & 8.788 & 0.000 \\
\hline
\end{tabular}

$\mathrm{n}=360 \mathrm{p}>.001$.

Table 3 illustrates the direct and indirect effects of both the psychological empowerment and the leadership empowerment behavior on work engagement. We note that the direct effect of the variable of the empowering leadership behavior was negative and non-significant, with $\beta=-0.0 .06$ and $\mathrm{p}=0.67$. The psychological empowerment was also shown to have a direct positive effect on the work engagement with $\beta=0.89$ and $\mathrm{T}=$ 5.058 and $\mathrm{P}=0.000$. Also, there is a direct positive correlation between the independent variable of the study, which is the empowering leadership behavior and the mediating variable (psychological empowerment), where the value of $\beta 0.76=\mathrm{T}=8.788$ and $\mathrm{P}=0.000$.

The results of the model indicated that there are indirect effects between the leadership empowerment behavior 
and the work engagement as mediated by psychological empowerment (0.67), and the total effect of both variables on the work engagement was 0.61 . Based on these values, the fourth hypothesis is accepted where there is a significant effect of psychological empowerment as it is fully mediating the relationship between the leadership empowerment behavior and work engagement.

In order to confirm these results, the Sobel criterion was used for interstitial mediation testing, which is achieved when the measured estimates are not less than 0.08 , and the value of $\mathrm{P}$ is significant. The weighted estimates of the result are equal to the multiplying the value of the first path (independent and mediator) by the second path (mediator and dependent). This result is reflected in table (4) obtained from the Sobel Test. The standard estimates reached $(0.89 \mathrm{X} 0.76)=0.676$, the value of $\mathrm{T}=4.168$, and $\mathrm{P}=0.000)$, which is higher than that of the Sobel standard (0.08) and thus the mediation effect of the psychological empowerment is proven. So, the fourth hypothesis is accepted.

Table 4. Sobel test results to detect the indirect effects of interventional mediation of psychological empowerment

\begin{tabular}{lllllll}
\hline Exogenous & Endogenous & Mediation & Estimate & S.E. & C. R & P \\
\hline $\begin{array}{l}\text { Empowering } \\
\text { behavior }\end{array}$ & Leadership & Job Engagement & Psychological Empowerment & 0.676 & 0.162 & 4.168 \\
\hline
\end{tabular}

$\mathrm{N}=360 \mathrm{p}>0.001$.

\section{Discussion and Study Implications}

The study aimed to test the effect of the empowering leadership behavior and psychological empowerment as causal variables on the work engagement as one of the positive trends directed towards the tasks assigned to the workers by applying to the employees in the cement sector in Upper Egypt.

The results did not support the first hypothesis that predicted the direct positive relationship between the empowering leadership behaviors. This result raises some questions concerning the leader- member relationship, antecedents of employees' engagement such as organizational support, organizational justice (Rasheed et al, 2013), moral climate (Taghipour \& Dezfuli, 2013) and the organizational culture in cement factories. Also, this is may be because of the nature of the work engagement. That is, some writers explain this nature by focusing on the state aspects of work engagement, and how the level of work engagement changes and develops over time (Kahn, 1990; Sonnentag, Binnewies, \& Mojza, 2010). In this sense, work engagement is seen as a reflection of individuals' momentary feelings about themselves and their environment at a certain point in time (Xanthopoulou, Bakker, Heuven, Demerouti, \& Schaufeli, 2008), which implies that work engagement is a dynamic experience (Sonnentag, 2003, Støren, 2017). This implies that examining the work engagement should be better done through longitudinal studies (Støren, 2017, Xanthopoulou, Bakker, \& Kantas, 2012).

The results of this study provide a statistical evidence that the employees' perception of the empowering leadership behavior is likely to be positively affecting psychological empowerment. Results of our study are in the line with the results of some previous studies (e.g., Peachey, 2002; Ahearne et al., 2005; Raub \& Robert, 2010).

These findings indicate that, in spite of the importance of the empowerment as management practices (administrative empowerment) by the leader, the empowerment as a psychic state for subordinates (psychological empowerment) has the same importance at work. Also, it should be noted that psychological empowerment may contribute to the empowerment of the leaders. That is to say, there is a mutual influence between the two variables as indicated by the Dierendonck and Dijkstra (2012) study, which tested the relationship of the mutual influence between the behaviors of the empowered leader's behavior and psychological empowerment. This emphasized the need to test this relationship in the Egyptian context in future studies.

The results of the present study confirmed the positive relationship between psychological empowerment and the work engagement. These results are consistent with that of some of previous studies (e.g., Stander \& Rothmann, 2010; Taghipour \& Dezfuli, 2013; Khatri \& Khushboo, 2013; Jose \& Mampilly, 2014). Such results reflect the ability of psychological empowerment as an independent variable to interpret work engagement as a dependent variable.

The main concern of this study was to measure the mediating role of the psychological empowerment in the 
relationship between the empowering leadership behavior and the work engagement. The results confirmed that psychological empowerment had an indirect effect on the relationship between leadership empowerment behavior and work engagement.

These results are consistent with some previous studies, (eg, Albrecht \& Andreetta, 2011; Raub \& Robert, 2010; Zhu et al., 2012; Raub \& Robert, 2012; Klerk \& Stander, 2014). Also, the results reflect the importance of psychological empowerment as a mediating variable in interpreting the relationship between the behavior of the empowered leader and the work engagement. So, it is expected that the psychologically empowered employees can clearly perceive the behaviors of the empowered leaders.

\section{Conclusion}

The positive correlation between the empowering leadership behavior and psychological empowerment indicates that if organizations want to maintain psychological empowerment, they should support the behavior of the empowered leader by giving the managers more professional authority. At the same time, the relationship between empowering leadership behaviors and work engagement is clearly improved when mediated by psychological empowerment. This implies that the way to more leadership influence will go through more psychological empowerment given to the employees.

The study proved that the psychological empowerment is fully mediating the relationship between the empowered leader's behavior and work engagement. This may draw the attention of the management at the cement factories to increase the area of empowering both leaders and employees. Leaders in turn should work more with enhancing the leader-member relations. This may lead to enhancing the effect of empowering leadership behaviors on work engagement in the future.

The cement factories need to work out a plan of interventions that include giving the current leader some administrative and financial authorities, creating second-class leaders, developing the skills of current leaders, raising the level of employees' self-efficacy. Also, the administration at these factories is recommended to give employees opportunities to determine their career, and rework the vision of the factory to include the concept of work engagement.

\section{The Study Limits}

Finally, various limitations of this study ought to be considered. Data collection relies mainly on the selfadministered questionnaire in a cross-sectional study. This may lead to the bias associated with the self-administered questionnaire may be due to social desirability bias (Özarallı, 2015). At the same time, the nature of work engagement as discussed earlier showed that it is better to examine the work engagement and related variables in a multi-level and longitudinal study. All of these limitations represent avenues of future research in work engagement in Egypt.

\section{References}

Abdel Salam, E. M., Shawky, A. Y, El-Nahas, T., \& Nawar, Y. S. (2013). The relationship among job satisfaction, motivation, leadership, communication, and psychological empowerment: An Egyptian case study. S.A.M. Advanced Management Journal, 78(2), 33-50.

Ahearne, M., Mathieu, J., \& Rapp, A. (2005). To empower or not to empower your sales force? An empirical examination of the influence of leadership, empowerment behavior on customer satisfaction and performance. Journal of Applied Psychology, 90(5), 945-955. http://dx.doi.org/10.1037/0021-9010.90.5.945

Albrecht, S. L., \& Andreetta, M. (2011). The influence of empowering leadership, empowerment and engagement on affective commitment and turnover intentions in community health service workers: Test of a model, Leadership in Health Services, 24(3), 228-237. http://dx.doi.org/10.1108/17511871111151126

Amundsen, S., \& Martinsen, O. L. (2014). Empowering Leadership: Construct Clarification, Conceptualization, and Validation of a New Scale. Leadership Quarterly, 25, 487-511. http://dx.doi.org/doi:10.1016/j.leaqua.2013.11.009

Avolio, B., Zhu, J. W., \& Bhatia, K. P. (2004). Transformation Leadership and Organizational Commitment: Mediating Role of Psychological Empowerment and Moderating Role of Structural Distance. Journal of Organizational Behavior, 25, 951-968. http://dx.doi.org/10.1002/job.283

Bordin, C., Bartram, T., \& Casimir, G. (2007). The Antecedents \& Consequences of Psychological Empowerment Among Singaporean IT Employees. Management Research News, 30(1), 34-46. DOI: http://dx.doi.org/10.1108/01409170710724287 
Boudrias, J. S., Gaudreau, P., Savoie, A., \& Morin, A. J. S. (2009). Employee empowerment: From managerial practices to employees' behavioral empowerment. Leadership \& Organization Development Journal, 30(7), 625-638. http://dx.doi.org/doi/abs/10.1108/01437730910991646

Burke, C. S., Stagl, K. C., Klein, C., Goodwin, G. F., Salas, E., \& Halpin, S. M. (2006). What type of leadership behaviors are functional in teams? A meta-analysis. The Leadership Quarterly, 17, 288-307. https://doi.org/10.1016/j.leaqua.2006.02.007

Carless, S. A. (2004). Does Psychological Empowerment Mediate The Relationship between Psychological Climate and Job Satisfaction? Journal of Business and Psychology, 18(4), 405-425.

Carson, C. M., \& King Jr., J. E. (2005). Leaving leadership: Solving Leadership Problems through Empowerment. Management Decision, 43, 1049-1053.

Conger, J. A., \& Kanungo, R. N. (1988). The Empowerment Process -Integrating theory and Practice. Academy of Management Review, 13(3), 471-482. http://dx.doi.org/10.2307/258093

Czarnowsky, M. (2008). Learning's Role in Employee Engagement: An ASTD Research Study. Alexandria, VA. American Society for Training \& Development.

Dee, J., Henkin, A., \& Duemer, L. (2003). Structural Antecedents and Psychological Correlates of Teacher Empowerment. Journal of Educational Administration, 41, 257-277. http://dx.doi.org/10.1108/09578230310474412

Dierendonck, V. D., \& Dijkstra, M. (2012). The Role of the Follower in the Relationship between Empowering Leadership and Empowerment: A Longitudinal Investigation. Journal of Applied Social Psychology, 42(S1), 1-20. http://dx.doi.org.10.1111/j.1559-1816.2012.01022.x

El-Masadi, A. (2003). The effect of Employees empowerment on their motivation. Journal of Faculty of Commerce for Scientific Researches, 40(2), 44-64.

El-Mobied, A. M., \& Awad, A. M. (2003). Determinants and outcomes of employees' empowerment in administrative jobs at Ain Shams University Hospitals. Scientific Review of Economics and Commerce, Ain $40(1), 21-44$.

El-Sayed, M. M. (2003). Employees' empowerment, Scientific Review of Economics and Commerce, Ain Shams University, Egypt, 40(4), 122-143.

Ghadi, M. Y., Fernando, M., \& Caputi, P. (2012).Transformational Leadership and Work Engagement: the Mediating Effect of Meaning in Work. Leadership \&Organization Development Journal, 34(6), 532-550. http://dx.doi.org/10.1108/LODJ-10-2011-0110

Greco, P., Laschinger, H., \& Wong, C. (2006). Leader Empowering Behaviors, Staff Nurse Empowerment and Work Engagement/Burnout. Nursing leadership, $19(4), \quad$ 41-56. http://dx.doi.org/doi:10.12927/cjnl.2006.18599

Gregory, B. T., Albritton, M. D., \& Osmonbekov, T. (2010). The mediating role of psychological empowerment on the relationships between $\mathrm{P}-\mathrm{O}$ fit, job satisfaction, and in-role performance. Journal of Business Psychology, 25(4), 639-647. http://dx.doi.org/10.1007/s10869-010-9156-7

Hakimi, N., Van Knippenberg, D., \& Giessner, S. (2010). Leader empowering behavior: The leader's perspective. British Journal of Management, 21(3), 701-716. http://dx.doi.org/10.1111/j.1467-8551.2010.00703.x

Harter, J. K., Schmidt, F. L., Agrawal, S., \& Plowman, S. K. (2013). The Relationship Between Engagement at Work and Organizational Outcomes: Meta-Analysis, Gallup Inc.

Hayder, M. F. (2001). A study of factors affecting employees' empowerment at Local Government Units in Sharqyah Governorate. Scientific Review of Commerce and Finance, 2, 21-54.

Hui, C. (1994). Effects of Leader Empowering Behaviors and Followers Personal Control, Voice, and Self-Efficacy on in-Role Performance: An Extension and Empirical Test of Conger and Kanungo's Empowerment Process Model. Doctoral Dissertation, Indiana University.

Industrial Development Authority (IDA). (2018). Statistics and trends of Cement Industry in Egypt. Cairo: IDA publications.

Jose, G., \& Mampilly, S. R. (2014). Psychological Empowerment as a Predictor of Employee Engagement: An Empirical Attestation, Global Business Review, 15(1), 93-104.

Kanter, R. (1977). Men and Women in Corporations. New York: Basic Books. 
Khan, W. A. (1990). Psychological conditions of personal engagement and disengagement at work. Academy of Management Journal, 33(4), 692-724. http://dx.doi.org/10.2307/256287

Khatri, P., \& Khushboo. (2013). A Study of Empowerment and Engagement of ITES/BPO Professionals in Delhi/NCR. International Journal of Information Technology, 5(2), 610-618.

Kim, M., \& Beehr, T. A. (2018). Can Empowering Leaders Affect Subordinates' Well-Being and Careers Because They Encourage Subordinates' Job Crafting Behaviors? Journal of Leadership and Organizational Studies, 25(2), 184-196. https://doi.org/10.1177/1548051817727702

Klerk, S., \& Stander, M. W. (2014). Leadership Empowerment Behavior, Work Engagement and Turnover Intention: The Role of Psychological Empowerment. Journal of Positive Management, 5(3), 28-45. http://dx.doi.org/10.12775/JPM.2014.018

Kumar, V., \& Pansari, A. (2014). The construct, measurement, and impact of employee engagement: A marketing perspective, Customer Needs and Solutions, 1, 52-67.

Lishchinsky, O. S., \& Tsemach, S. (2014). Psychological Empowerment as a Mediator between Teachers' Perceptions of Authentic Leadership and Their Withdrawal and Citizenship Behaviors. Educational Administration Quarterly, 50(4), 675-712. http://dx.doi.org/10.1177/0013161X13513898

Lorinkova, N. M., \& Perry, S. J. (2017). When Is Empowerment Effective? The Role of Leader-Leader Exchange in Empowering Leadership, Cynicism, and Time Theft. Journal of Management, 43(5), 1631-1654. http://dx.doi.org/10.1177/0149206314560411

May, D. R., Gilson, R. L., \& Harter, L. M. (2004). The Psychological Conditions of Meaningfulness, Safety and Availability and the Engagement of the Human Spirit at Work. Journal of Occupational and Organizational Psychology, 77(1), 11-37. http://dx.doi.org/10.1348/096317904322915892

Menon, S. T. (1999). Psychological empowerment: Definition, measurement, and validation. Canadian Journal of Behavioural Science / Revue canadienne des sciences du comportement, 31(3), 161-164. http://dx.doi.org/10.1037/h0087084

Namasivayam, K., Guchait, P., \& Lei, P. (2014). The influence of leader empowering behaviors and employee psychological empowerment on customer satisfaction. International Journal of Contemporary Hospitality Management, 26(1), 69-84. http://dx.doi.org/10.1108/IJCHM-11-2012-0218

O’Neill, B. S., \& Arendt, L. A. (2008).Psychological Climate and Work Attitudes: The Importance of Telling the Right Story. Journal of Leadership \& Organizational Studies, 14, 353-370. http://dx.doi.org/10.1177/1548051808315553

Olivier, A. L., \& Rothmann, S. (2007). Antecedents of Work Engagement in a Multinational Oil Company. $S A$ Journal of Industrial Psychology, 33(3), 49-56.

Özarallı, N. (2015). Linking empowering leader to creativity: the moderating role of psychological (felt) empowerment, Procedia - Social and Behavioral Sciences, 181, 366-376. http://dx.doi.org/10.1016/j.sbspro.2015.04.899

Peachey, G. A. (2002). The Effect of Leader Empowering Behaviors on Staff Nurses Workplace Empowerment, Psychological Empowerment, Organizational Commitment And Absenteeism. Doctoral Dissertation of Clinical Health Sciences (Nursing) McMaster University.

Ram, P., \& Prabhakar, P. V. (2011). The role of employee engagement in work-related outcomes. Interdisciplinary Journal of Research in Business, 1(3), 47-61.

Randolph, W. A., \& Kemery, E. R. (2011). Managerial Use of Power Bases in a Model of Managerial Empowerment Practices and Employee Psychological Empowerment. Journal of Leadership \& Organizational Studies, 18(1), 95-106. http://dx.doi.org/10.1177/1548051810379798

Rasheed, A., Khan, S., \& Ramzan. M. (2013). Antecedents and Consequences of Employee Engagement: The Case of Pakistan, Journal of Business Studies Quarterly, 4(4), 183-200.

Raub, S., \& Robert, C. (2010). Differential Effects of Empowering Leadership on in-Role and Extra-Role Employee Behaviors: Exploring the Role of Psychological Empowerment and Power Values. Human Relations, 63(11), 1743-1770. http://dx.doi.org/10.1177/0018726710365092

Raub, S., \& Robert, C. (2012). Empowerment, Organizational Commitment, and Voice Behavior in the Hospitality Industry: Evidence from a Multinational Sample. Cornell Hospitality Quarterly, 54(2), 136-148. 
Saif, N. I., \& Saleh, A. S. (2013). Psychological Empowerment and Job Satisfaction in Jordanian Hospitals. International Journal of Humanities and Social Science, 3(16), 250-257.

Schaufeli, W. B. (2015). Engaging leadership in the job demands-resources model, Career Development International, 20(5), 446-463. http//dx.doi.org/10.1108/CDI-02-2015-0025

Schaufeli, W. B., \& Bakker, A. B. (2004). Job demands, Job resources and their relationship with burnout and engagement: a multi- sample study. Journal of Organizational Behavior, 25, 293-315. http://dx.doi.org/10.1002/job.248

Schaufeli, W. B., Salanova, González-Romá, V., \& Bakker, A. B. (2002). The Measurement of Engagement and Burnout: A Two Sample Confirmatory Factor Analytic Approach. Journal of Happiness Studies, 3, 71-92. http://dx.doi.org/doi:10.1023/A:1015630930326

Shelton, K. (1997). Beyond counterfeit leadership: How you can become a more authentic leader. Provo, UT: Executive Excellence.

Shelton, S. T. (2002). Employees, Supervisors, and Empowerment in the Public Sector: The Role of Employee Trust. Doctoral Dissertation in Public Administration Raleigh. Faculty of North Carolina State University.

Sobel, M. E. (1982). Asymptotic Confidence Intervals for Indirect Effects in Structural Equation Models. Sociological Methodology, 13, 290-312.

Sonnentag, S. (2003). Recovery, work engagement, and proactive behavior: A new look at the interface between non-work and work. Journal of Applied Psychology, 88(3), 518-528.

Sonnentag, S., Binnewies, C., \& Mojza, E. J. (2010). Staying well and engaged when demands are high: The role of psychological detachment. Journal of Applied Psychology, 95, 965-976. http://dx.doi.org.10.1037/a0020032

Spreitzer, G. M. (1995), Psychological empowerment in the workplace: Dimensions, measurement, and validation. Academy of Management Journal, 38(5), 1442-1465. http://dx.doi.org/10.2307/2568665

Stander, M. W., \& Rothmann, S. (2010). Psychological empowerment, job insecurity and employee engagement. South African Journal of Industrial Psychology, 36(1), 1-8. http://dx.doi.org/10.4102/sajip.v36i1.849

Støren, K. S. (2017). Exploring the Dynamics of Work Engagement with Empowering Leadership as Predictor: A Longitudinal Multi-level Approach. Master's thesis, University of Oslo, Norway.

Sze, C. C., \& Angeline, T. (2011). Engaging Employees to Their Jobs: Role of Exchange Ideology as a Moderator, African Journal of Business Management, 5(10), 3986-3994. http://dx.doi.org/10.5897/AJBM11.215

Taghipour, A., \& Dezfuli, Z. K. (2013). Designing and Testing a Model of Antecedents of Work Engagement, Procedia - Social and Behavioral Sciences, 84, 149-154. https://doi.org/10.1016/j.sbspro.2013.06.526

The World Bank. (2014). Egypt: Too Many Regulations Breed Corruption, World Bank News.

Tuckey. M. R., Bakker, A. B., \& Dollard, M. F. (2012). Empowering Leaders Optimize Working Conditions for Engagement: A Multilevel Study. Journal of Occupational Health Psychology, 17(1), 15-27. http://dx.doi.org.10.1037/a0025942.

Ugwu, F. O., Onitsha, I. E., \& Rodríguez-Sánchez, A. M. (2014). Linking Organizational Trust with Employee Engagement: the Role of Psychological Empowerment. Personnel Review, 43(3), 377-400.

Winston, B. E., \& Patterson, K. (2006). An Integrative Definition of Leadership. International Journal of Leadership Studies, 1(2), 6-66.

Xanthopoulou, D., Bakker, A. B., \& Kantas, A. (2012). Measuring burnout and work engagement: Factor structure, invariance, and latent mean differences across Greece and the Netherlands, International Journal of Business Science and Applied Management, 7(2), 40-52.

Xanthopoulou, D., Bakker, A. B., Heuven, E., Demerouti, E., \& Schaufeli, W. B. (2008). Working in the sky: A diary study on work engagement among flight attendants. Journal of Occupational Health Psychology, 13, 345-356. http://dx.doi.org.doi:10.1037/1076-8998.13.4.345

Xu, J., \& Thomas, H. C. (2011). How Can Leaders Achieve High Employee Engagement? Leadership \& Organization Development Journal, 32(4), 399-416. http://dx.doi.org/10.1108/01437731111134661

Zhang, X., \& Bartol, K. M. (2010). Linking empowering leadership and employee creativity: The influence of 
psychological empowerment, intrinsic motivation and creative process engagement. Academy of Management Journal, 53(1), 107-128. http://dx.doi.org/10.5465/AMJ.2010.48037118

Zhang, X., \& Sims, H. (2005). Leadership, Collaborative Capital, and Innovation: in M. Beyerlein, S. Beyerlein, \& F. Kennedy (Eds.), Advances in Interdisciplinary Studies of Work Teams (pp. 211-236).

Zhu, W., Sosik, J., Riggio, R. E., \& Yang, B. (2012). Relationships between Transformational and Active Transactional Leadership and Followers' Organizational Identification: The Role of Psychological Empowerment. Journal of Behavioral and Applied Management, 13(3), 186-212.

\section{Copyrights}

Copyright for this article is retained by the author(s), with first publication rights granted to the journal.

This is an open-access article distributed under the terms and conditions of the Creative Commons Attribution license (http://creativecommons.org/licenses/by/4.0/). 